(C). Є. Горбань, В. К. Кондратюк, I. І. Ракша

ДУ «Інститут педіатрї̈, акушерства і гінекологї

імені академіка О. М. Лук'янової НАМН України», Київ

\title{
ОЦІНКА ЕХОГРАФІЧНИХ ПОКАЗНИКІВ У ЖІНОК З ГІПЕРПРОЛІФЕРАТИВНОЮ ПАТОЛОГІЕЮ ЕНДОМЕТРІЯ
}

Мета дослідження - визначити ехограсрічні особливості органів малого таза у жінок репродуктивного віку з неатиповою гіперпроліфреративною патологією ендометрія (НГПЕ).

Матеріали та методи - Ультразвукове дослідження (УЗД) органів малого таза проведено 184 пацієнткам репродуктивного віку з НГПЕ, яких було поділено на 3 групи: I - жінки з неатиповою гіперплазією ендометрія (HГЕ) (n=60); II - пацієнтки 3 поліпами тіла матки (ПТМ) (n=62); III - хворі з поєднаною НГПЕ (НГЕ+ПТМ) (n=62). Контрольну групу склали 30 жінок репродуктивного віку без наявності гінекологічної патології.

Результати дослідження та їх обговорення. Збільшення розмірів тіла матки встановлено у більшості хворих основних груп - у 126 (68,5 \%) осіб. У 143 (77,7 \%) хворих із НГПЕ ультразвукова картина характеризувалась вираженим поліморфізмом. НГЕ характеризувалась збільшенням товщини та зміною ехоструктури ендометрія, невідповідністю показників дню менструального циклу. При ПтМ спостерігали гетерогенність ендометрія та наявність ехопозитивних утворів овальної фрорми розміром 0,2-0,4 см однорідної структури. У 35,3 \% жінок із НГПЕ виявлено неоднорідність тканини з переважанням гіперехогенних включень діаметром 0,1-0,3 см внаслідок вогнищ фріброзу і кальцинозу базального шару ендометрія, що $є$ ехограсрічними ознаками хронічного ендометриту. Для наочності надано рисунки ультразвукових зображень різних видів HГПЕ.

Висновки. Саме трансвагінальне УЗД органів малого таза в жінок із НГПЕ є доступним, швидким та інфрормативним діагностичним методом у виявленні такої гінекологічної патології у жінок репродуктивного віку.

Ключові слова: гіперпроліферативна патологія ендометрія; поліп тіла матки; гіперплазія ендометрія; репродуктивний вік; ультразвукове дослідження.

ОЦЕНКА ЭХОГРАФИЧЕСКИХ ПОКАЗАТЕЛЕЙ У ЖЕНЩИН С ГИПЕРПРОЛИФЕРАТИВНОЙ ПАТОЛОГИЕЙ ЭНДОМЕТРИЯ

Цель исследования - определить эхографические особенности органов малого таза у женщин репродуктивного возраста с неатипичной гиперпролисеративной патологией эндометрия (НГПЭ).

Материалы и методы. Ультразвуковое исследование (УЗИ) органов малого таза проведено 184 пациенткам репродуктивного возраста с НГПЭ, которые были распределены на 3 группы: I - женщины с неатипичной гиперплазией эндометрия (НГЭ) (n=60); II - пациентки с полипами тела матки (ПТМ) (n=62); III - больные с сочетанной НГПЭ (НГЭ+ПТМ) (n=62). Контрольную группу составили 30 женщин репродуктивного возраста без наличия гинекологической патологии.

Результаты исследования и их обсуждение. Увеличение размеров тела матки установлено у большинства обследованных основных групп - у 126 (68,5 \%) человек. У 143 (77,7 \%) больных с НГПЭ ультразвуковая картина характеризуется выраженным полиморфизмом. НГЭ характеризовалась увеличением толщины и изменением эхоструктуры эндометрия, несоответствием показателей дню менструального цикла. При ПтМ наблюдались гетерогенность эндометрия и наличие эхопозитивных образований овальной фрормы размером 0,2-0,4 см однородной структуры. У 35,3\% женщин с НГПЭ обнаружена неоднородность ткани с преобладанием гиперэхогенных включений диаметром 0,1-0,3 см вследстви очагов фииброза и кальциноза базального слоя эндометрия, эхографически соответствующих признакам хронического эндометрита. Для наглядности предоставлены рисунки ультразвуковых изображений различных видов НГПЭ.

Выводы. Именно трансвагинальное УзИ органов малого таза у женщин с НГПЭ является доступным, быстрым и инсормативным диагностическим методом в выявлении такой гинекологической патологии у женщин репродуктивного возраста.

Ключевые слова: гиперпролиферативная патология эндометрия; полип тела матки; гиперплазия эндометрия; репродуктивный возраст; ультразвуковое исследование.

EVALUATION OF ULTRASOUND PARAMETERS IN WOMEN WITH ENDOMETRIAL HYPERPROLIFERATIVE PATHOLOGY

The aim of the study - to determine the echographic features of the pelvic organs in women of reproductive age with nonatypical hyperproliferative pathology of the endometrium (NHPE).

Materials and Methods. Ultrasound examination (ultrasound) of the pelvic organs was performed for 184 patients of reproductive age with NHPE, divided into 3 groups: I - women with non-atypical endometrial hyperplasia $(\mathrm{NEH})(\mathrm{n}=60)$; II - patients with polyps of the uterus (PU) $(n=62)$; III - patients with combined NHPE (NEH + PU) $(n=62)$. The control group consisted of 30 women of reproductive age without the presence of gynecological pathology.

Results and Discussion. An increase in the size of the uterus was found in most of the examined main groups - in 126 $(68.5 \%)$ people. In $143(77.7 \%)$ patients with NHPE, the ultrasound picture is characterized by pronounced polymorphism. NEH was characterized by an increase in thickness and a change in the echostructure of the endometrium, mismatch of the indicators on the day of the menstrual cycle. With PU, endometrial heterogeneity and the presence of echopositive oval formations with a size $(0.2-0.4) \mathrm{cm}$ of a homogeneous structure were observed. Tissue heterogeneity with prevalence of hyperechoic inclusions with a diameter of $(0.1-0.3) \mathrm{cm}$ due to foci of fibrosis and calcification of the basal layer of the endometrium, echographically consistent with signs of chronic endometritis was found in $35.3 \%$ of women with NHPE. For clarity, drawings of ultrasound images of various types of NHPE are provided. 
Conclusions. It is transvaginal ultrasound of the pelvic organs in women with NGPE that is an affordable, fast and informative diagnostic method in identifying such a gynecological pathology in women of reproductive age.

Key words: endometrial hyperproliferative pathology; uterine body polyp; endometrial hyperplasia; reproductive age; ultrasound.

встУп. Гіперпролісеративні захворювання ендометрія у жінок фертильного віку є потенційною причиною зниження репродуктивного потенціалу. Частота цієї патології не має тенденції до зниження і досягає $17,5 \%[1,2]$. Патологічні процеси ендометрія складають значну частку у структурі гінекологічної захворюваності та є однією з найчастіших причин госпіталізації жінок до стаціонару [3, 4].

Незважаючи на багаторічні наукові дослідження, які спрямовані на розробку та впровадження нових методів лікування, досі має місце висока частота рецидивів гіперпроліферативних захворювань ендометрія [3, 5]. Поряд із цим, необґрунтоване застосування малоінвазивної внутрішньоматкової хірургії, широкий вибір препаратів гормональної терапії у лікуванні патологічних станів ендометрія визначають актуальність доопераційної діагностики стану ендометрія [1, 4, 6, 7].

Диференційна діагностика гіперпроліферативних станів ендометрія має вирішальне значення у визначенні тактики лікування пацієнток. На сьогодні ехографрія $€$ провідним методом діагностики захворювань органів малого таза $[8,9,10]$. Вимірювання величини передньозаднього розміру серединного маткового ехо (М-ехо) має найбільше прогностичне значення при патологічних станах ендометрія.

Методом вибору ультразвукової діагностики (УЗД) при гіперпролісреративних станах ендометрія $€$ трансвагінальна ехограсрія, яка передбачає застосування високочастотних датчиків, що забезпечує кращу візуалізацію акустичного відображення від ендометрія. Застосування трансабдомінального доступу під час УЗД погіршує оцінку М-ехо внаслідок часткового поглинання ехосигналів підшкірною жировою клітковиною [3, 4].

Сучасні діагностичні методи, такі як комп'ютерна томографрія та магнітно-резонансна томографрія, не завжди дозволяють диференціювати варіанти патології ендометрія $[11,12]$. Тому для початкової візуалізації гіперпроліферативних захворювань ендометрія, зокрема поліпів тіла матки, в рутинній практиці рекомендовано проведення трансвагінального ультразвукового дослідження (ТВУзД) (рівень доказовості В (2)) у проліферативну фразу менструального циклу (табл. 1) [13].

Підвищена увага клініцистів та дослідників до проблеми гіперпроліфреративних захворювань ендометрія також зумовлена досить високим ризиком її малігнізації [17], що

Таблиця 1. Характеристика трансвагінального ультразвукового дослідження у діагностиці поліпів тіла матки

\begin{tabular}{||l|c|}
\hline \multicolumn{1}{|c|}{ Характеристика } & $\%$ \\
\hline Чутливість & $19-96$ \\
\hline Специфрічність & $53-100$ \\
\hline $\begin{array}{l}\text { Позитивна прогностична } \\
\text { цінність }\end{array}$ & $75-100$ \\
\hline $\begin{array}{l}\text { Негативна прогностична } \\
\text { цінність }\end{array}$ & $87-97$ \\
\hline
\end{tabular}

вимагає подальшого вдосконалення та персоналізації [18] і пошуку нових підходів у діагностиці та лікуванні даної патології $[14,15]$.

МЕТА ДОСЛІДЖЕННЯ - визначити ехографічні особливості органів малого таза у жінок репродуктивного віку 3 неатиповою гіперпроліферативною патологією ендометрія.

МАТЕРІАЛИ ТА МЕТОДИ. Дослідження проводили на базі відділення планування сім'ї та оперативної реабілітації репродуктивної фрункції жінок ДУ «Інститут педіатрії, акушерства і гінекології імені академіка О. М. Лук'янової НАМН України». Було обстежено 184 пацієнтки репродуктивного віку, у яких морфологічно верифіковано неатипову гіперпроліферативну патологію ендометрія. Вік обстежених жінок в середньому склав $(36,1 \pm 2,54)$ року. Залежно від результатів патогістологічного дослідження, хворих було поділено на 3 групи: 1-шу групу складали жінки $з$ неатиповою гіперплазією ендометрія (НГЕ) (n=60); 2-гу групу - пацієнтки, які мали поліпи тіла матки (ПТМ) (n=62); до 3-ї групи увійшли хворі 3 поєднаною неатиповою гіперпроліферативною патологією ендометрія (ПНГПЕ) (поліпи з гіперплазією ендометрія) ( $n=62)$. Контрольну групу склали 30 жінок репродуктивного віку без наявності гінекологічної патології.

УЗД органів малого таза виконували на апараті Esaote MyLab 20 plus. Застосовували трансабдомінальні конвексні датчики із частотою акустичних коливань 3,5 МГц і трансвагінальні датчики із частотою 6,5 і 7 МГц. Сонографію у пацієнток проводили в динаміці менструального циклу - на 5-7-й день та 22-24-й день. Під час дослідження визначали положення і розміри матки (довжину, передньозадній розмір, ширину), структуру міометрія, наявність і характер його змін. Особливу увагу приділяли вивченню М-ехо - відображенню від ендометрія і стінок порожнини матки: вимірювали величину передньо-заднього розміру, оцінювали структуру, контури, наявність деформації порожнини матки. Досліджували ехоструктуру шийки матки та ендоцервіксу. Оцінювали розміри та об'єм яєчників, число фоллікулів. Звертали увагу на ознаки функціональної активності яєчників (стан фролікулярного апарату, наявність жовтого тіла), а також наявність патологічних структур, ознак злукових процесів.

Статистичну обробку отриманих даних здійснювали з використанням прикладного програмного пакета Statistica 6.0.

РЕЗУЛЬТАТИ ДОСЛІДЖЕННЯ ТА ЇХ ОБГОВОРЕНня. Враховуючи коливання розмірів тіла матки залежно від фрази менструального циклу, фріксували результати, отримані на 5-7-й день менструального циклу (табл. 2).

Середні показники довжини тіла матки у жінок 3 НГЕ склали $(53,2 \pm 4,7)$ мм, у пацієнток, які мали ПТМ, вона дорівнювала $(52,2 \pm 3,8)$ мм, у хворих із ПНГПЕ, відповідно, $(54,0 \pm 2,7)$ мм проти $(46,7 \pm 1,8)$ мм у жінок контрольної групи $(p<0,05)$. Передньо-задній розмір тіла матки в середньому склав у жінок I групи $(46,8 \pm 2,0)$ мм, II групи - $(49,5 \pm 1,5)$ мм, III групи - $(47,0 \pm 1,8)$ мм проти 
Таблиця 2. Результати вимірювань тіла матки при ультразвуковому дослідженні обстежених жінок на 5-7-й день

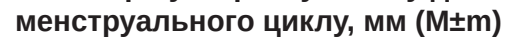

\begin{tabular}{|c|c|c|c|c|}
\hline & \multicolumn{3}{|c|}{ Групи обстежених з гіперпроліферативною патологією ендометрія } & \multirow{2}{*}{$\begin{array}{l}\text { Здорові жінки } \\
\quad(n=25)\end{array}$} \\
\hline & $\begin{array}{c}\text { I група (хворі з НГЕ) } \\
(\mathrm{n}=60)\end{array}$ & $\begin{array}{c}\text { II група (хворі з ПТМ) } \\
\text { (n=62) }\end{array}$ & $\begin{array}{c}\text { III група (хворі з ПНГПЕ) } \\
\text { (n=62) }\end{array}$ & \\
\hline Довжина тіла матки (мм) & $(53,2 \pm 4,7)^{\star}$ & $(52,2 \pm 3,8)^{*}$ & $(54,0 \pm 2,7)^{\star}$ & $46,7 \pm 1,8$ \\
\hline $\begin{array}{l}\text { Передньо-задній розмір тіла } \\
\text { матки (мм) }\end{array}$ & $(46,8 \pm 2,0)^{\star}$ & $(49,5 \pm 1,5)^{\star}$ & $(47,0 \pm 1,8)^{\star}$ & $39,1 \pm 4,6$ \\
\hline Ширина тіла матки (мм) & $(46,4 \pm 3,2)^{*}$ & $(48,1 \pm 2,4)^{\star}$ & $(50,0 \pm 1,3)^{\star}$ & $43,2 \pm 4,9$ \\
\hline M-exo (мм) & $(8,43 \pm 1,6)^{\star}$ & $(8,0 \pm 1,8)^{\star}$ & $(9,0 \pm 1,4)^{*}$ & $5,78 \pm 1,5$ \\
\hline
\end{tabular}

Примітка. * різниця достовірна відносно показників контрольної групи $(p<0,05)$.

$(39,1 \pm 4,6)$ мм у здорових жінок $(p<0,05)$. Середні показники ширини тіла матки в обстежених основних груп склали: $(46,4 \pm 3,2)$ мм -у хворих з НГЕ, $(48,1 \pm 2,4)$ мм -у пацієнток із ПТМ, $(50,0 \pm 1,3)$ мм - в обстежених із ПНГПЕ, порівняно з показниками здорових жінок - $(43,2 \pm 4,9)$ мм $(p<0,05)$.

Вищенаведені дані доводять, що ехографрічні середні показники розмірів тіла матки у жінок з неатиповою гіперпроліферативною патологією ендометрія не мають достовірної різниці між основними групами, але відрізняються від аналогічних значень у здорових жінок. Збільшення розмірів тіла матки встановлено у більшості представниць основних груп - у 126 (68,5 \%) осіб.

Шийка матки сонографрічно у більшості обстежених хворих із неатиповою гіперпроліферативною патологією ендометрія не відрізнялася від здорових жінок. Розміри шийки матки коливались залежно від репродуктивного анамнезу пацієнток.

У середньому в групі жінок з НГЕ довжина шийки матки склала $(37 \pm 3,2)$ мм, ширина - $(28 \pm 3,2)$ мм; у групі хворих із ПТМ довжина шийки матки склала $(36 \pm 1,2)$ мм, ширина - $(27 \pm 3,1)$ мм; у групі пацієнток із ПНГПЕ довжина шийки матки склала $(35 \pm 1,6)$ мм, ширина - $(28 \pm 1,4)$ мм; у групі здорових жінок довжина шийки матки склала $(36 \pm 1,9)$ мм, ширина - $(26 \pm 1,7)$ мм, $p>0,05$.

Структура шийки матки у $28(46,7 \%)$ жінок I групи, у $23(37,1 \%)$ обстежених II групи, у 24 (38,7\%) пацієнток III групи та у 6 (20,0 \%) здорових жінок була неоднорідною за рахунок поодиноких та/або численних ехонегативних утворів різного розміру (максимальний розмір до 1,0 cм).
Одним з ультразвукових критеріїв наявності гіперпроліферативних захворювань ендометрія $€$ його потовщення у визначені дні менструального циклу [16, 9, 5]. Відповідно до отриманих нами результатів, величина передньо-заднього розміру М-ехо у пацієнток основних груп коливалася від 8 до 22 мм, склавши в середньому $(14,5 \pm 4,1)$ мм.

Так, за даними трансвагінального УЗД на 5-7-й день менструального циклу, товщина ендометрія у жінок з НГЕ склала $(8,43 \pm 1,6)$ мм, у пацієнток 3 ПТМ - $(8,0 \pm 1,8)$ мм, у хворих з ПНГПЕ - $(9,0 \pm 1,4)$ мм проти $(5,78 \pm 1,5)$ мм у жінок контрольної групи $(p<0,05)$ (табл. 3$)$.

Ультразвукове зображення (УЗ-зображення) ендометрія на 7-й день менструального циклу в пацієнтки з ПТМ відображено на рисунку 1.

На 22-24-й день менструального циклу середні показники товщини ендометрія у пацієнток з НГЕ склали $(15,1 \pm 3,2)$ мм, у хворих з ПТМ - $(14,8 \pm 1,70)$ мм, в обстежених із ПНГПЕ - $(16,2 \pm 1,2)$ мм, склавши в контрольній групі $(9,7 \pm 3,9)$ мм $(p<0,05)$ (рис. 2$)$.

Таким чином, аналіз отриманих результатів показав, що найбільша товщина (більше 16 мм) визначалася у жінок III групи - при поєднанні НГЕ та ПТМ (рис. 3).

Визначальним діагностичним критерієм у виявленні патології ендометрія є оцінка структурних змін ендометрія. У всіх жінок (100 \%) контрольної групи та 41 (22,3\%) пацієнтки, які мали неатипову гіперпролісреративну патологію ендометрія, його структура в I фразу менструального циклу була тришаровою, візуалізувалась гіперехогенна смуга, яка утворювалась від змикання задньої та передньої стінок матки.

Таблиця 3. Частота прояву деяких ультразвукових характеристик ендометріальної тканини при ультразвуковому дослідженні пацієнток із неатиповою гіперпроліферативною патологією ендометрія, $\overline{\mathrm{X}} \pm \mathrm{SD}$

\begin{tabular}{|c|c|c|c|c|}
\hline \multirow[b]{2}{*}{ Показник } & \multicolumn{3}{|c|}{ Частота прояву, $\overline{\mathrm{X}} \pm \mathrm{SD}$} & \multirow{2}{*}{$\begin{array}{c}\text { Рівень } \\
\text { значущості } \\
\text { відмінності, р }\end{array}$} \\
\hline & $\begin{array}{c}\text { I група (хворі з НГЕ) } \\
(\mathrm{n}=60)\end{array}$ & $\begin{array}{c}\text { II група (хворі з ПТМ) } \\
\text { (n=62) }\end{array}$ & $\begin{array}{c}\text { III група (хворі з ПНГПЕ) } \\
\text { (n=62) }\end{array}$ & \\
\hline Підвищена ехогенність & $48(80,0 \%)$ & $43^{3}(69,3 \%)$ & $55^{2}(88,7 \%)$ & 0,03 \\
\hline Неоднорідна структура & $46^{2}(76,7 \%)$ & $32^{1,3}(51,6 \%)$ & $50^{2}(80,6 \%)$ & $<0,001$ \\
\hline Десрормація М-ехо & $14^{2,3}(23,3 \%)$ & $54^{1,3}(87,1 \%)$ & $40^{1,2}(64,5 \%)$ & $<0,001$ \\
\hline Гіперехогенні включення & - & $53(90,3 \%)$ & $52(83,9 \%)$ & $>0,99$ \\
\hline Розширення порожнини матки & $5(8,3 \%)$ & $7(11,7 \%)$ & $6(9,6 \%)$ & 0,86 \\
\hline $\begin{array}{l}\text { Фіброз та кальциноз } \\
\text { базального шару }\end{array}$ & $19(31,6 \%)$ & $24(38,7 \%)$ & $22(35,4 \%)$ & 0,72 \\
\hline
\end{tabular}

Примітка. При проведенні порівняння використано критерій Крускала-Уолліса. При проведенні постеріорних попарних порівнянь використано критерій Данна: ${ }^{1}$ - відмінність від групи Г статистично значима, p<0,05; ${ }^{2}-$ відмінність від групи $П$ статистично значима, $p<0,05 ;^{3}$ - відмінність від групи П+Г статистично значима, $p<0,05$. 


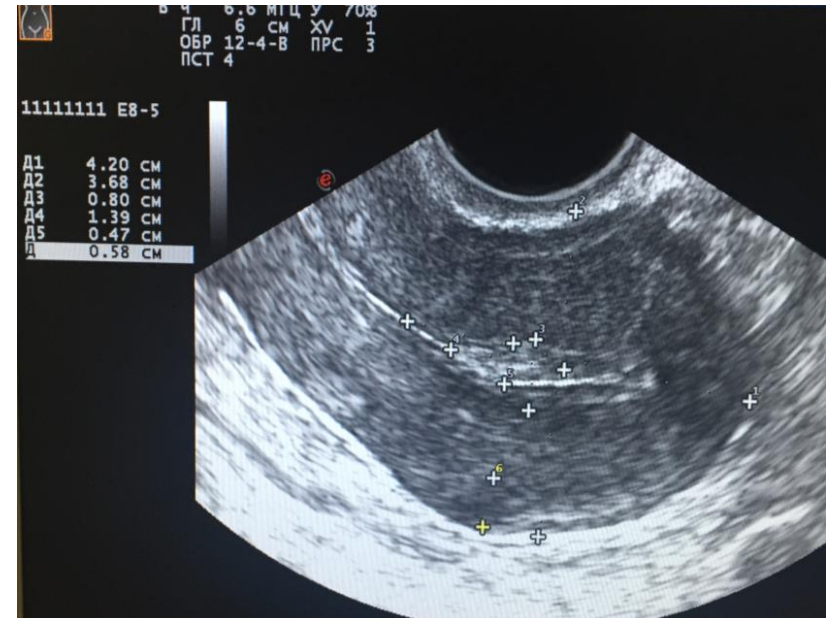

Рис. 1. Ультразвукове зображення ендометрія пацієнтки О. віком 33 роки (7-й день менструального циклу, група з поліпами тіла матки).

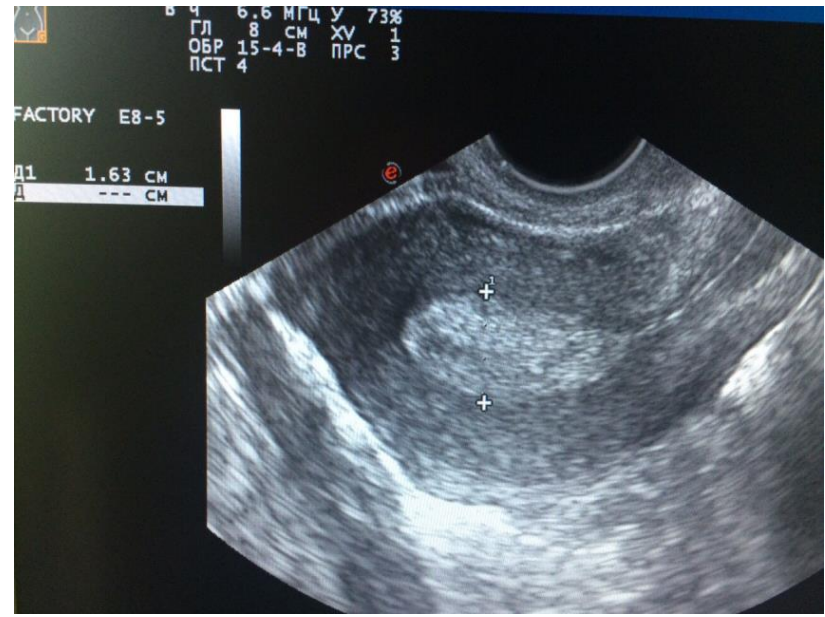

Рис. 2. Ультразвукове зображення ендометрія пацієнтки К. віком 36 років (22-й день менструального циклу, група 3 НГЕ).

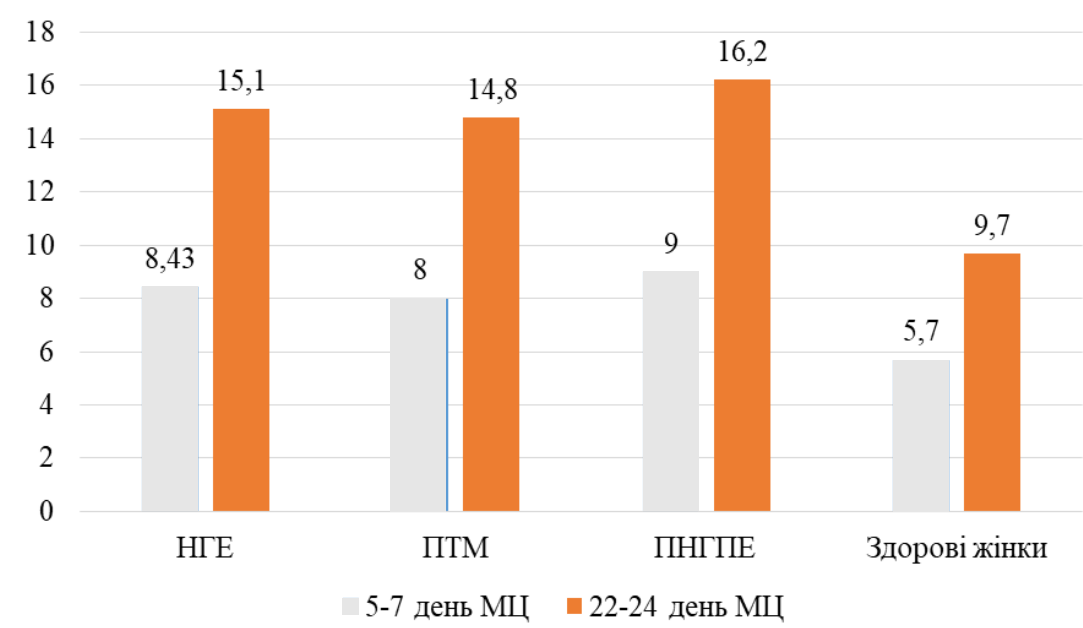

Рис. 3. Показники вимірювань товщини ендометрія при ультразвуковому дослідженні жінок обстежених груп, мм.

Також, слід наголосити, що в більшості пацієнток 3 неатиповою гіперпроліферативною патологією ендометрія - у 143 (77,7 \%) випадках ультразвукова картина характеризувалася вираженим поліморфізмом (табл. 3). Так, під час вивчення особливостей порожнини матки та стану її слизової оболонки виявлено: підвищену ехогенність ендометріальної тканини у 48 (80,0 \%) жінок, які мали НГЕ, у 43 (69,3 \%) обстежених із ПТМ та у 55 (88,7\%) пацієнток із ПНГПЕ, що при порівнянні між ними мало відмінність на рівні $p=0,03$.

Неоднорідну структуру з множинними дрібними гіпоабо анехогенними включеннями розміром до 1,5 мм іноді з ефектом акустичного підсилення, верифріковано у 46 (76,7 \%) жінок I групи, у 32 (51,6 \%) хворих II групи, у 50 (80,6 \%) пацієнток III групи, що мало відмінність на рівні $p<0,001$ між групами, де ПтМ був визначений як гіперпроліферативна монопатологія.

Десрормацію місця дотику переднього та заднього листків ендометрія найбільш часто було візуалізовано у 54 (87,1 \%) обстежених II групи та у 40 (64,5\%) представниць III групи на відміну від 14 (23,3 \%) жінок I групи, p<0,001 (рис. 4).

Ехопозитивні утвори овальної фрорми розміром 0,2-0,4 мм однорідної структури, що відповідали ПТМ, спостерігалися у 53 (90,3 \%) пацієнток, які мали ізольовані ПТМ, та у 52 (83,9 \%) обстежених з ПНГПЕ, що не мало відмінності, p>0,99 (рис. 5).

у 56 (93,3 \%) випадках у групі жінок з ПтМ та у 55 (88,7 \%) обстежених з ПНГПЕ виявлено поодинокі поліпи, а множинні поліпи - у 4 (6,7 \%) та 7 (11,6 \%) хворих відповідно.

У деяких випадках інтерпретація ехографрічної картини була утруднена за наявності залозистих ПТМ, які за рахунок конфрігурації по фрормі порожнини матки мали листоподібну або сплощену форму та не призводили до потовщення М-ехо. Звукопровідність таких поліпів була наближеною до звукопровідності ендометрія, що також значно погіршувало їхню візуалізацію.

Розширення порожнини матки до 0,3-0,6 мм виявлено у 5 (8,3 \%) жінок I групи, у 7 (11,7\%) обстежених II групи та у $6(9,6 \%)$ хворих III групи, p=0,86.

Неоднорідність М-ехо з переважанням гіперехогенних включень діаметром 0,1-0,3 см внаслідок вогнищ фріброзу 


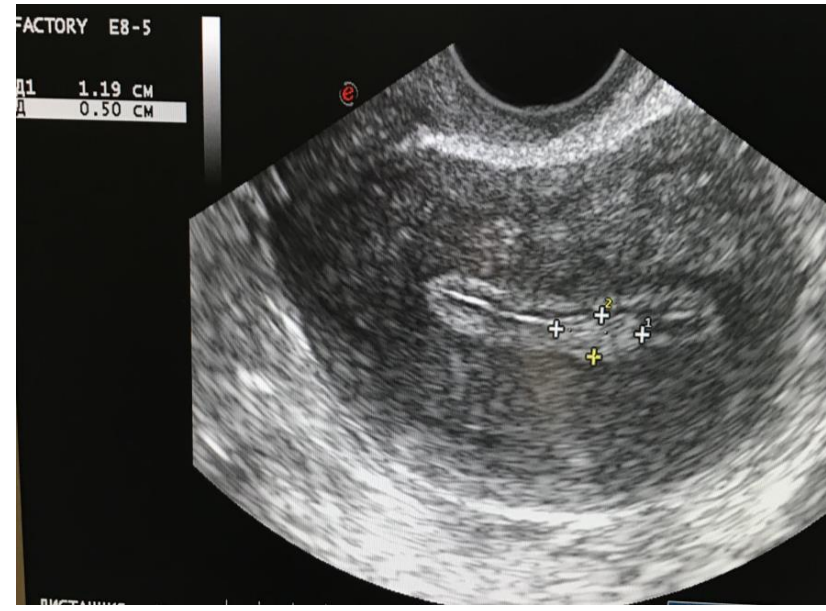

Рис. 4. Ультразвукове зображення ендометрія з десормацією М-ехо пацієнтки В. віком 28 років (8-й день менструального циклу, група з ПтМ).

і кальцинозу базального шару ендометрія спостерігали приблизно в третині випадків у хворих із неатиповою гіперпроліферативною патологією ендометрія: у 19 (31,6 \%) пацієнток I групи, у 24 (38,7 \%) обстежених II групи та у $22(35,4 \%)$ жінок III групи, p=0,72.

Слід зазначити, що приблизно така ж кількість обстежених жінок з усіх груп мала чітку невідповідність зображення ендометрія дню менструального циклу. Так, це встановлено у 19 (31,7 \%) жінок з НГЕ, у 20 (32,3 \%) обстежених з ПТМ, у 24 (38,7 \%) хворих з ПНГПЕ та лише в 1 (4,0 \%) жінки 3 контрольної групи вперше.

За результатами сонографрічного обстеження середні розміри яєчників у жінок з неатиповою гіперпроліфреративною патологією ендометрія склали у хворих I групи $(6,4 \pm 3,1) \mathrm{cm}^{3}$, у пацієнток II групи - $(7,2 \pm 1,4)$ см$^{3}$, в обстежених III групи - $(7,0 \pm 0,8) \mathrm{cm}^{3}$, що достовірно не відрізнялося від аналогічних показників у групі здорових жінок - $(7,1 \pm 2,3) \mathrm{cm}^{3}(p>0,05)$.

У структурі яєчників домінантний фролікул у першу фразу менструального циклу розміром більше 12,0 мм визначали у 37 (61,7 \%) хворих 3 неатиповою гіперплазією ендометрія, у 41 (66,1 \%) представниці групи з поліпами тіла матки, у 39 (62,9 \%) обстежених з поєднаною неатиповою гіперпроліфреративною патологією ендометрія та у 21 (70,0 \%) жінки з контрольної групи. Мультифолікулярна ехоструктура яєчників була притаманна 23 (12,5 \%) жінкам основних груп та 3 (10,0 \%) здоровим жінкам.

Під час УЗД підтвердженням факту овуляції вважали наявність вільної рідини параоваріально або в дугласовому просторі та формування жовтого тіла на місці домінантного фолікула.

Так, слід зауважити, що фракт наявності овуляції був підтверджений лише у 38 (63,3 \%) жінок із НГЕ, у 41 (66,1 \%) хворої, які мали ізольовані ПтМ, у 39 (62,9 \%) хворих із ПНГПЕ та майже у всіх 56 (93,3 \%) представниць контрольної групи, що в котрий раз підкреслює системність змін у репродуктивній системі за наявності гіперпроліферативної ендометріальної патології.

Реєстрація колірних ехосигналів у структурі утвору під час допплерівського дослідження дозволяє дисреренціювати поліпи від внутрішньоматкових синехій та згортків крові (рис. 6, 7), де кровотік був відсутній.

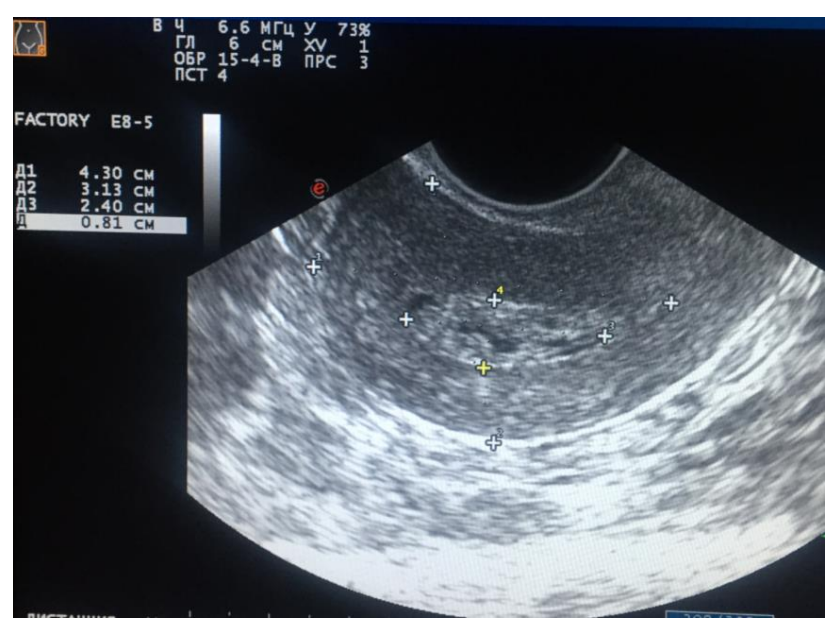

Рис. 5. Ультразвукове зображення ПТМ з НГЕ пацієнтки С. віком 33 роки (7-й день менструального циклу, група 3 ПНГПЕ).

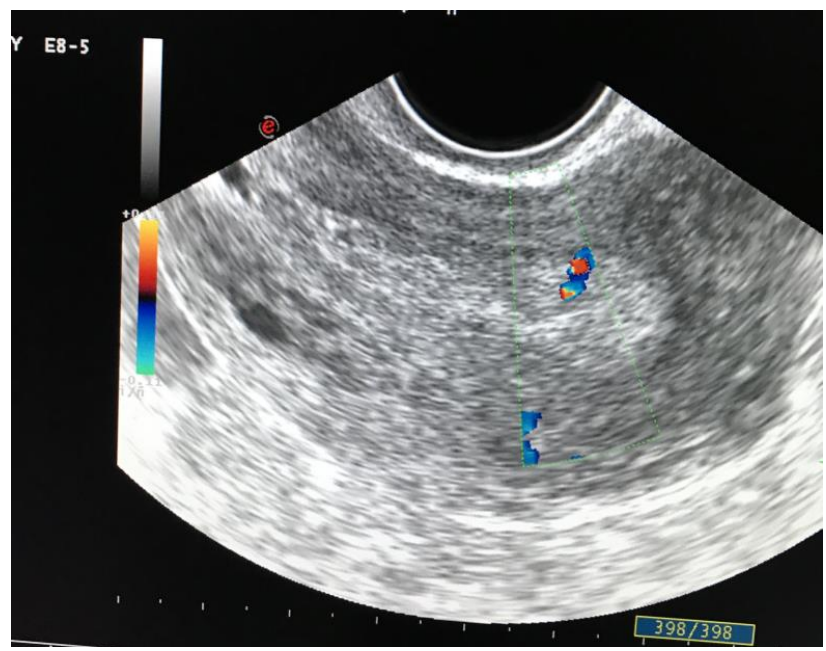

Рис. 6. Ультразвукове зображення судинної ніжки поліпа тіла матки при колірному картуванні у пацієнтки Л. віком 28 років (23-й день менструального циклу, група з ПНГПЕ).

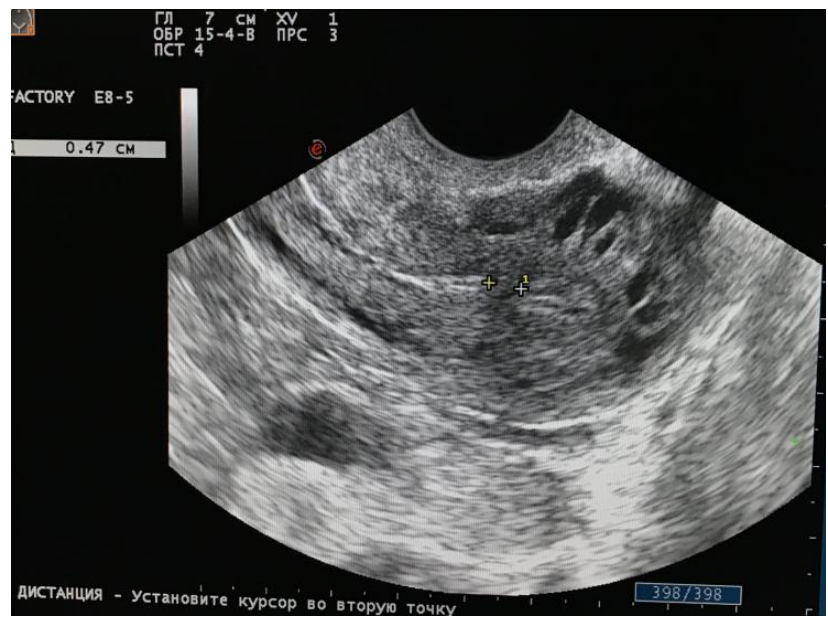

Рис. 7. Ультразвукове зображення синехії порожнини матки у пацієнтки Д. віком 34 роки (5-й день менструального циклу, група з НГЕ). 
Наявність судинної ніжки поліпа тіла матки виявлено у переважної більшості обстежених: у $44(77,4 \%)$ жінок, які мали ПтМ, та у 24 (38,7 \%) хворих із поєднаною гіперпроліферативною патологією ендометрія.

Отже, вищенаведені дані щодо ехографічних особливостей порожнини матки та ендометріальної тканини за її гіперпроліферативних змін свідчать, що саме трансвагінальне ультразвукове дослідження $€$ точним та інсрормативним діагностичним методом у виявленні такої гінекологічної патології у жінок репродуктивного віку.

ВИСНОВКИ. Ультразвуковими критеріями встановлення діагнозу гіперплазії ендометрія були: збільшення товщини та підвищення ехогенності ендометрія, невідповідність показників дню менструального циклу, зміна ехоструктури ендометрія - візуалізувалась гомогенною з підвищеною або зниженою звукопровідністю чи гетерогенною 3 наявністю дрібних анехогенних включень.

\section{СПИСОК ЛІТЕРАТУРИ}

1. Павловская М. А. Гиперплазия эндометрия у женщин репродуктивного возраста: диагностика, лечение и профрилактика рецидивирования : автореф. дис. на соискание учёной степени канд. мед. наук : 14.01.01 / М. А. Павловская ; Гродн. гос. мед. ун-т. - Минск, 2015. - 25 с.

2. Incidence of endometrial hyperplasia / S. Reed, K. Newton, W. Clinton [et al.] // Am. J. Obstet. Gynecol. - 2009. Vol. 200, No. 6. - P. 678.

3. Візір К. М. Фактори ризику розвитку неатипової гіперплазії ендометрія у жінок репродуктивного віку на сучасному етапі / К. М. Візір, В. Г. Дубініна // Здоровье женщины. - 2015. - № 2. - С. 111-113.

4. Лечение пациенток с эндометриальной гиперплазией / С. А. Леваков, Н. А. Шешукова, О. В. Большакова, Е. А. Обухова // Пробл. репродукции. - 2017. - Т. 23, № 2. - C. 33-36.

5. Kotdawala P. Evaluation of endometrium in perimenopausal abnormal uterine bleeding / P. Kotdawala, S. Kotdawala, N. Nagar // J. Midlife Health. - 2013. - Vol. 4, No. 1. - P. 16-21.

6. Гроховська М. В. Оцінка клітинних процесів при гіперплазіях ендометрію у жінок з екстрагенітальною патологією / М. В. Гроховська // Арх. клін. мед. - 2015. - № 1. - C. 11-13.

7. Сучасні аспекти діагностики гіперпластичних процесів ендометрія у жінок репродуктивного віку / В. О. Бенюк, Я. М. Винярський, В.М.Гончаренко, В.В.Курочка // Таврический медико-биологический вестник. - 2012. - Т. 15, № 2, 4. 2 (58). - С. 20-22.

8. Дубініна В. Г. Стан маткового кровотоку при гіперплазії ендометрія у жінок у репродуктивний період / В. Г. Дубініна, К. М. Візір // Здоровье женщины. - 2016. - № 7. - С. 141-143.

9. Caserta M. P. Through thick and thin: a pictorial review of the endometrium / M. P. Caserta, C. W. Bolan, M. J. Clingan // Abdominal Radiology. - 2016. - Vol. 41 - P. 2312-2329.

10. Do postmenopausal women with thickened endometrium on trans-vaginal ultrasound in the absence of vaginal bleeding need hysteroscopic assessment? A Pilot Study / R. Laiyemo, W.
1. У пацієнток з поліпами тіла матки за результатами ультразвукової оцінки спостерігали гетерогенність ехоструктури ендометрія, наявність ехопозитивних утворів овальної фороми розміром $(0,2-0,4)$ см однорідної структури.

2. При поєднанні неатипової гіперплазії ендометрія та поліпів тіла матки ехографічно відзначали збільшення товщини та підвищення ехогенності ендометрія, гетерогенність ехоструктури ендометрія, деформацію М-ехо.

3. У 35,3 \% жінок з гіперпролісреративною патологією ендометрія виявлено неоднорідність М-ехо 3 переважанням гіперехогенних включень діаметром $(0,1-0,3)$ см внаслідок вогнищ фріброзу і кальцинозу базального шару ендометрія, що $€$ ехограсрічними ознаками хронічного ендометриту.

ПЕРСПЕКТИВИ ПОДАЛЬШИХ ДОСЛІДЖЕНЬ. ВИвчення ехограсрічних особливостей ендометріальної тканини за різних видів ії̈ гіперпроліферативних змін дає змогу виділити основні ультразвукові критерії таких патологічних утворів на різних етапах їх формування.

Dudill, S. E. Jones, H. Browne // J. Obstet. Gynaecol. - 2016. - Vol. 36, No. 2. - P. 223-226.

11. Efficacy of contrast-enhanced CT in assessing the endometrium / J. Grossman, Z. Ricci, A. Rozenblit [et al.] // Am. J. Roentgenol. - 2008. - Vol. 191, No. 3. - P. 664-669.

12. Predicting the coexistence of an endometrial adenocarcinoma in the presence of atypical complex hyperplasia / E. Robbe, S. van Kuijk, E. de Boed [et al.] // Int. J. Gynecol. Cancer. - 2012. - Vol. 22, No. 7. - P. 1264-1272.

13. AAGL Practice Report: Practice Guidelines for the Diagnosis and Management of Endometrial Polyps // J. of Minimally Invasive Gynecol. - 2012. - Vol 19, No. 1.

14. Lacey J. V. Absolute risk of endometrial carcinoma during 20-year follow-up among women with endometrial hyperplasia / J. V. Lacey, M. E. Sherman, B. B. Rush // J. Clin. Oncol. - 2010. - Vol. 28, No. 5. - P. 788-792.

15. The management of polyps in female reproductive organs / V. Tanos, K. E. Berry, J. Seikkula [et al.] // Int. J. of Surgery. - 2017. - Vol. 43. - P. 7-16.

16. Доленко О. В. Этиопатогенетические аспекты и комплексная ультрасонографрия гиперпластических процессов эндометрия / О. В. Доленко // Междунар. мед. журн. - 2015. - № 2. - С. 95-97.

17. Захворюваність на рак тіла матки на територіях Тернопільської області, постраждалих внаслідок аварії на Чорнобильській атомній електростанції / Б. Д. Кривокульський, І.В.Жулкевич, Л. В. Шкробот, Д. Б. Кривокульський // Матеріали наук.-практ. конор. 3 міжнар. участю «30 років 3 дня катастрофи на ЧАЕС: унікальний досвід та досягнення Харківського інституту медичної радіології у аварійному медичному реагуванні» (28-29 квітня 2016 року, Харків) // Укр. радіол. журнал. - 2016. - Дод. 2. - С. 70.

18. Жулкевич І. В. Персоналізація в онкології: індивідуальний підхід до профрілактики тромбоемболічних ускладнень при пангістеректомії / І.В.Жулкевич, Б. Д. Кривокульський // Вісник соціальної гігієни та організації охорони здоров'я України. - 2018. - № 4. - С. 11-18. 


\section{REFERENCES}

1. Pavlovskaya, M.A. (2015). Giperplaziya endometriya u zhenshchin reproduktivnogo vozrasta: diagnostika, lecheniye i profilaktika retsidivirovaniya [Endometrial hyperplasia in women of reproductive age: diagnosis, treatment and prevention of relapse]. Extended Abstract of Candidate's thesis. Minsk: Grodn. State Medical University [in Russian].

2. Reed, S.D., Newton, K.M., Clinton, W.L., Epplein, M., Garcia, R., Allison, K., ..., \& Weiss, N.S. (2009). Incidence of endometrial hyperplasia. Am. J. Obstet. Gynecol., 200, 6, 678.

3. Vizir, K.M., \& Dubinina, V.H. (2015). Faktory ryzyku rozvytku neatypovoi hiperplazii endometria u zhinok reproduktyvnoho viku na suchasnomu etapi [Risk factors for development of atypical endometrial hyperplasia in women of reproductive age at the present stage]. Zdorovye zhenshchiny - Women's Health, 2, 111-113 [in Ukrainian].

4. Levakov, S.A., Sheshukova, N.A., Bolshakova, O.V., \& Obukhova, Ye.A. (2017). Lecheniye patsiyentok s endometrialnoy giperplaziyey [Treatment of patients with endometrial hyperplasia]. Probl. Reproduktsii - Probl. Reproductions, 23, 2, 33-36 [in Russian].

5. Kotdawala, P., Kotdawala, S., \& Nagar, N. (2013). Evaluation of endometrium in perimenopausal abnormal uterine bleeding. J. Midlife Health, 4, 1, 16-21.

6. Hrokhovska, M.V. (2015). Otsinka klitynnykh protsesiv pry hiperplaziiakh endometriiu u zhinok z ekstrahenitalnoiu patolohiieiu [Estimation of cellular processes in endometrial hyperplasia in women with extragenital pathology]. Arkhivy klinichnoi medytsyny - Archives of Clinical Medicine, 1, 11-13 [in Ukrainian].

7. Beniuk, V.O., Vyniarskyi, Ya.M., Honcharenko, V.M., \& Kurochka, V.V. (2012). Suchasni aspekty diahnostyky hiperplastychnykh protsesiv endometriia u zhinok reproduktyvnoho viku [Modern aspects of the diagnosis of endometrial hyperplastic processes in women of reproductive age]. Tavrycheskiy medikobiologicheskiy vestnyk - Taurida Medical and Biological Bulletin, 15, 2, (part 2 (58)), 20-22 [in Ukrainian].

8. Dubinina, V.H., \& Vizir, K.M. (2016). Stan matkovoho krovotoku pry hiperplazii endometriia u zhinok u reproduktyvnyi period [The state of uterine blood flow in endometrial hyperplasia in women in the reproductive period]. Zdorovye zhenshchiny Women's Health, 7, 141-143 [in Russian].

9. Caserta, M.P., Bolan, C.W., \& Clingan, M.J. (2016). Through thick and thin: a pictorial review of the endometrium. Abdominal Radiology, 41, 2312-2329.

10. Laiyemo, R., Dudill, W., Jones, S.E., \& Browne, H. (2016). Do postmenopausal women with thickened endometrium on trans-vaginal ultrasound in the absence of vaginal bleeding need hysteroscopic assessment? A Pilot Study. J. Obstet. Gynaecol., 36, 2, 223-226.

11. Grossman, J., Ricci, Z.J., Rozenblit, A., Freeman, K., Mazzariol, F., \& Stein, M.W. (2008). Efficacy of contrast-enhanced CT in assessing the endometrium. Am. J. Roentgenol., 191, 3, 664-669.

12. Robbe, E.J., van Kuijk, S.M., de Boed, E.M., Smits, L.J., van der Wurff, A.A., Kruitwagen, R.F., \& Pijnenborg, J.M. (2012). Predicting the coexistence of an endometrial adenocarcinoma in the presence of atypical complex hyperplasia. Int. J. Gynecol. Cancer, 22, 7, 1264-1272.

13. (2012). AAGL Practice Report: Practice Guidelines for the Diagnosis and Management of Endometrial Polyps. J. of Minimally Invasive Gynecol., 19, 1.

14. Lacey, J.V., Sherman, M.E., \& Rush, B.B. (2010). Absolute risk of endometrial carcinoma during 20-year follow-up among women with endometrial hyperplasia. J. Clin. Oncol., 28, 5, 788-792.

15. Tanos, V., Berry, K.E., Seikkula, J., Abi Raad, E., Stavroulis, A., Sleiman, Z., ..., \& Gordts, S. (2017). The management of polyps in female reproductive organs. Int. J. of Surgery, 43, 7-16.

16. Dolenko, O.V. (2015). Etiopatogeneticheskiye aspekty i kompleksnaya ultrasonografiya giperplasticheskikh protsessov endometriya [Etiopathogenetic aspects and complex ultrasonography of endometrial hyperplastic processes]. Mezhdunar. med. zhurn. - Intern. Med. Journal, 2, 95-97.

17. Kryvokulskyi, B.D., Zhulkevych, I.V., Shkrobot, L.V., \& Kryvokulskyi, D.B. (2016). Zakhvoriuvannist na rak tila matky na terytoriiakh Ternopilskoi oblasti postrazhdalykh vnaslidok avarii na Chornobylskii atomnii elektrostantsii [The incidence of uterine cancer in the territories of the Ternopil region affected by the accident at the Chernobyl nuclear power plant]. Proceedings of the International Scientific and Practical Conference "30 rokiv z dnia katastrofy na ChAES: unikalnyi dosvid ta dosiahnennia Kharkivskoho instytutu medychnoi radiolohii u avariinomu medychnomu reahuvanni" - "30 years since the Chernobyl disaster: unique experience and achievements of Kharkiv Institute of Medical Radiology in emergency medical response". Kharkiv. Ukrainskyi Radiolohichyi zhurnal-Ukrainian Radiological Journal, 2, 70 [in Ukrainian].

18. Zhulkevych, I.V., \& Kryvokulsky, B.D. (2018). Personalizatsiia v onkolohii: indyvidualnyi pidkhid do profilaktyky tromboembolichnykh uskladnen pry panhisterektomii [Personalization in oncology: individual approach to the prevention of thromboembolic complications during hysterectomy]. Visnyk sotsialnoi hihiieny ta orhanizatsii okhorony zdorovia Ukrainy - Bulletin of Social Hygiene and Health Protection Organization of Ukraine, 4, 11-18 [in Ukrainian]. 